\title{
PRE-GLACIAL AND POST-GLACIAL SINKHOLES IN SILURIAN CARBONATE ROCKS IN THE JAMES BAY LOWLAND, CANADA
}

Wanfang Zhou

Hana Engineers \& Consultants, $L L C$

Knoxville, Tennessee, United States, zhou_wanfang@yahoo.com

Mingtang Lei

Institute of Karst Geology

Guilin, Guangxi Province, China,lmt@karst.ac.cn

James W. LaMoreaux

PELA GeoEnvironmental Inc.

Tuscaloosa,Alabama, United States, JLamoreaux@pela.com

\section{Daniel S. Green}

PELA GeoEnvironmental Inc.

Tuscaloosa, Alabama, United States, dgreen@pela.com

\section{Abstract}

Sinkholes developed in the Paleozoic carbonate rocks within the James Bay lowland of Canada consist of preglacial sinkholes and post-glacial sinkholes. Most of the pre-glacial sinkholes were identified in the Upper Silurian Attawapiskat limestone at the Process Plant site after the thin peat and unconsolidated sediment cover were removed and in the Central Quarry site where the vertical profile of the Upper Attawapiskat limestone was exposed. One unique pre-glacial sinkhole was reported in the form of a bedrock trench, which cut through most of the Paleozoic formations to a depth of approximately $200 \mathrm{~m}$ below land surface. The pre-glacial sinkholes are filled with and covered by sediments that represent postglacial depositional environments. The post-glacial sinkholes have developed after the area emerged from the Tyrrell Sea approximately 4,400 years ago. Sinkholes with open drains and intermittent sinking streams are the primary form in the exposed reefal limestone of the Attawapiskat limestone along the Attawapiskat River and Nayshkootayaow River. Between the two major rivers post-glacial sinkholes have developed around perimeters of isolated bioherms, especially in the Bioherm Complex Zone between these two rivers. Although the mildly acidic peat water may have contributed to sinkhole formation at bioherms, the majority of the post-glacial sinkholes are likely linked to the pre-glacial ones, which provided the pre-existing conditions for the post-glacial sinkhole formation. The increases in hydraulic gradient in response to the isostatic uplift and seasonal fluctua- tions in shallow groundwater level have helped reactivate the pre-glacial sinkholes and have been the primary agents in eroding the overlying materials.

\section{Introduction}

The James Bay lowland, located approximately $90 \mathrm{~km}$ west of the town of Attawapiskat in northern Ontario, Canada, is a vast peatland consisting mostly of bogs and fens. A series of diamond-bearing kimberlite pipes were discovered in this area in the 1980s. The Victor kimberlite occurred within the Attawapiskat kimberlite cluster and was emplaced through approximately $250 \mathrm{~m}$ of Paleozoic carbonate rocks during the Jurassic Period (Webb et al., 2004). Figure 1 shows the locations of kimberlites and study area, which lie on the southern flank of the Cape Henrietta Maria Arch that separates the erosional remnants of the Hudson Bay and Moose River cratonic sedimentary basins (Wood et al., 2013; Ontario Geological Survey, 2007). Since discovery of the Victor kimberlites, various geotechnical, hydrogeological and environmental investigations have been conducted to evaluate the feasibility and environmental impacts of mining. The carbonates are country rocks in which dewatering wells would be installed for mining and are prone to karst development. Pliocene glaciations and post-glacial Tyrrell Sea deposition and continuous isostatic uplift have created a unique environment for karst development on the carbonate rocks. Similar karst features were first recognized and studied by Cowell in the early 1980s, and an area east of the Victor mine site was recommended as 


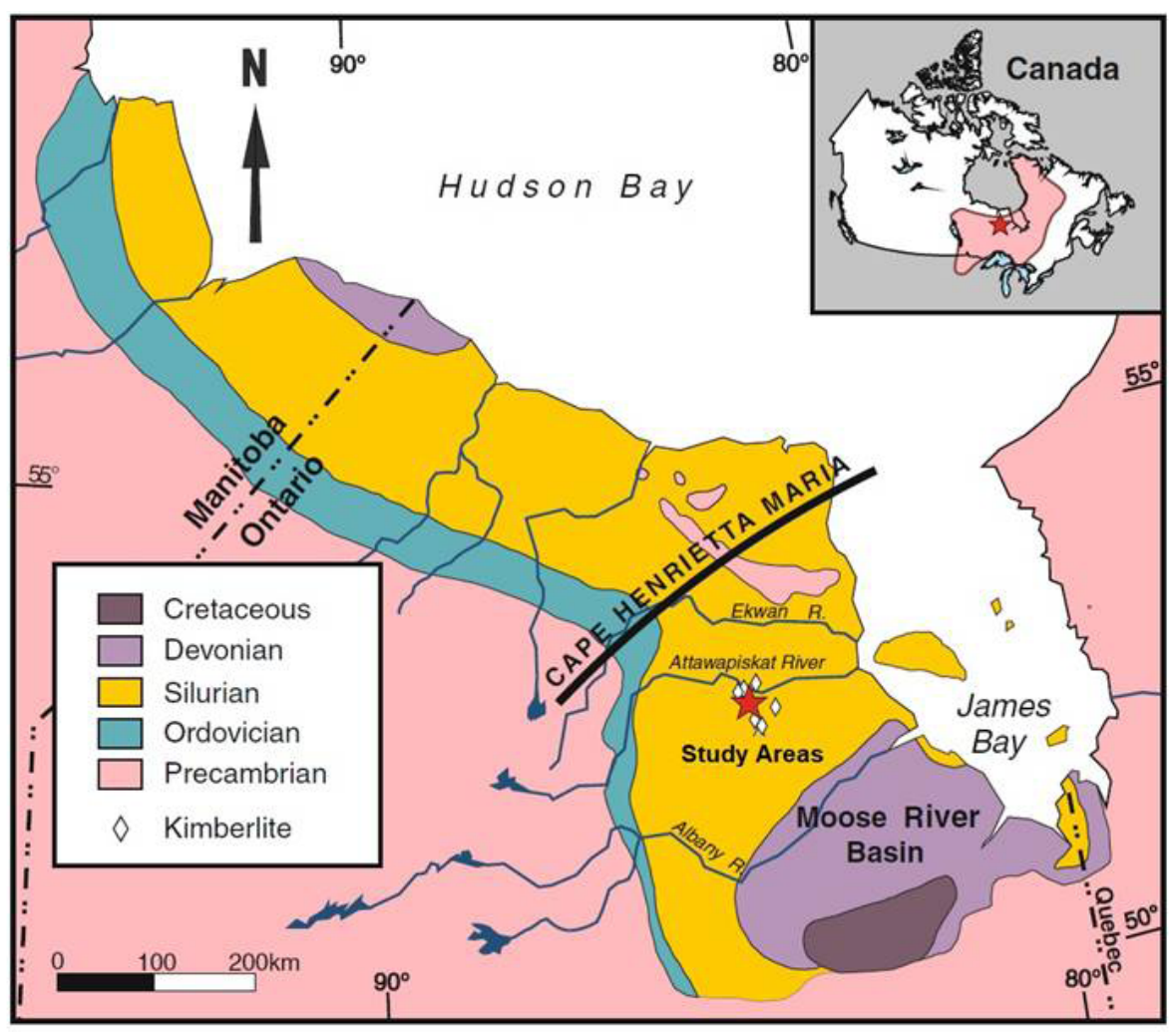

Figure 1 Location of study area

an Area of Natural and Scientific Interest for the unique karst features (Cowell, 1983). The karst and sinkhole study presented in this paper was to determine if karst features should be incorporated into the groundwater flow modeling for the Victor mine dewatering simulation (Atkinson et al., 2010) and to evaluate the risk of sinkhole occurrence during mine dewatering. Figure 2 shows location of the Victor mine and other significant features including Central Quarry, Process Plant, Exploration Camp, Bedrock Trench, and Bioherm Complex Zone that are related to this karst study. The Victor mine started operations in 2007 and ceased operation in 2019 (Gautrey, 2018).

\section{Geologic and Hydrogeologic Settings}

Table 1 summarizes the major lithologic units that are relevant to karst study of the area. The majority of the area between all the rivers remained relatively flat with poor drainage. Muskeg developed rapidly in these areas of poor drainage and covered the deposits further reducing their erosion. Only on the high ground along the larger rivers and on the remnant cores of ancient reefs (bioherms) that protrude above the surrounding topography, was there sufficient drainage for trees to grow. Underlying the muskeg is a series of glacial, marine and fluvial deposits. This series of deposits reflects the dynamic nature of the region over the relatively recent geologic past of approximately 8,000 years. At that time the last glacial ice mass made its final, and relatively rapid, retreat from the area (Cowell, 2004). The earth's surface had been depressed by the weight of the ice mass, and its removal created a basin that was quickly filled by the marine waters of the Tyrell Sea. During this time a generally uniform layer of clay and silt was deposited on the bottom of this shallow sea.

With the weight of the glaciers removed the earth's surface began to rebound at a rate of approximately $1 \mathrm{~m}$ per 100 years (Cowell, 1983). Approximately 4,400 years before present (BP) the land was once again exposed subaerially, and rivers began to flow across the surface depositing silt, sand, and gravel along their banks. As the land surface is generally flat, the high variability in the thickness of surficial deposits can be attributed to the highly irregular surface of the underlying bedrock. 


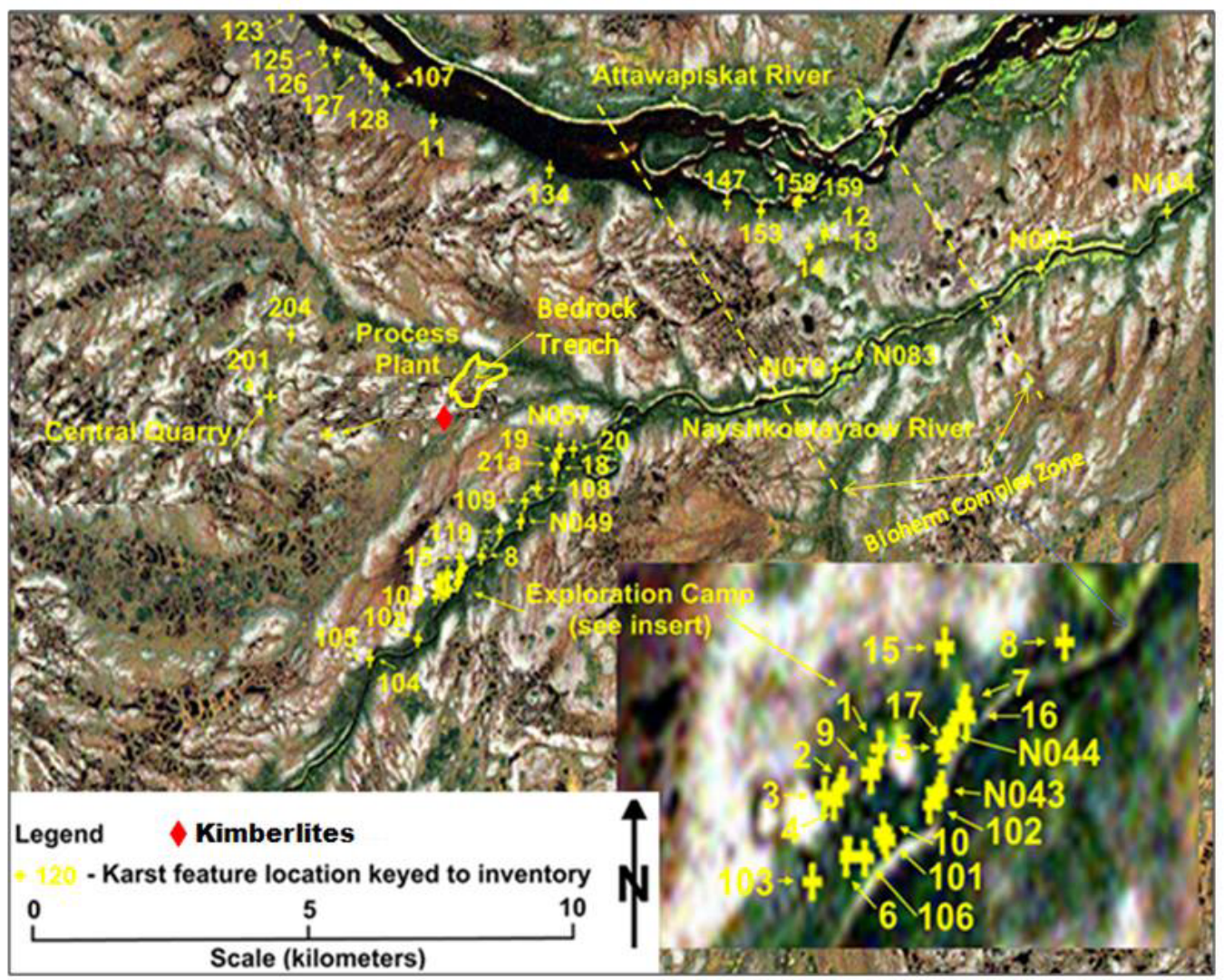

Figure 2 Distribution of karst features along and between Attawapiskat River and Nayshkootayaow River

The bedrock strata are flat-lying in the study area. The Attawapiskat Formation is the uppermost bedrock layer and has been divided into upper and lower units separated by a two to three-meter thick layer of blue-green mudstone. The blue-green mudstone is ubiquitous and forms a regional aquitard. The upper Attawapiskat unit extends to a depth of 58 to $68 \mathrm{~m}$ blow ground surface (bgs). Only the upper Attawapiskat unit is visible in outcrops and in the local Central Quarry.

The Ekwan River and the Severn River Formations underlie the Attawapiskat limestone extending to a depth of $250 \mathrm{~m}$. The Attawapiskat, Ekwan River, and Severn River formations are primarily composed of limestone and dolomite of middle Silurian age. At the base of sedimentary sequence are the Ordovician Redhead and Churchill River formations that contain mudstones, interbedded limestones, and evaporites.

The hydrogeological conditions in the study area are characterized with distinct aquifers and aquitards. The overburden sediment is the aquitard for the peat aquifer, whereas the blue-green mudstone is the aquitard for the upper Attawapiskat limestone aquifer (Gautrey, 2018). The regional groundwater flow in the area was from west to east under natural conditions. Local components of flow are typically towards the larger rivers, where the rivers incised into the bedrock. Vertical hydraulic connections between the aquifers are limited by the laterally extensive aquitards. Total dissolved solids measured in the groundwater indicated stratification, more evidence of lack of hydraulic communication between the aquifers. Fresh water is present in the peat and upper Attawapiskat limestone aquifers. The groundwater in the lower aquifer has chemical compositions reflecting a mixture of fresh water, relic Tyrell Sea water, and water in contact with evaporites. Saline groundwater is in the crystalline basement (Sader et al., 2011).

\section{Sinkhole Study}

Figure 2 presents a distribution of more than 100 karst features that were identified during the karst study along 


\begin{tabular}{|c|c|}
\hline Lithology & Description \\
\hline $\begin{array}{l}\text { Holocene Peat } \\
\text { Muskeg }\end{array}$ & $\begin{array}{l}\text { Peat covers the vast majority } \\
\text { of the surface at the site. The } \\
\text { peat is typically several meters } \\
\text { thick, with an upper, spongy, } \\
\text { transmissive zone and a deeper, } \\
\text { mucky, relatively non-trans- } \\
\text { missive zone. }\end{array}$ \\
\hline $\begin{array}{l}\text { Pliocene Post-gla- } \\
\text { cial Marine and } \\
\text { Fluvial Deposits }\end{array}$ & $\begin{array}{l}\text { Marine and fluvial deposits } \\
\text { comprise the overburden. The } \\
\text { overburden thickness varies } \\
\text { from absent where isolated } \\
\text { bioherms protrude through the } \\
\text { overburden and along some } \\
\text { of the larger rivers, to greater } \\
\text { than } 50 \mathrm{~m} \text { thick over former } \\
\text { bedrock valleys. }\end{array}$ \\
\hline $\begin{array}{l}\text { Silurian Upper } \\
\text { Limestone }\end{array}$ & $\begin{array}{l}\sim 15 \text { m thick bioherms, which } \\
\text { are highly porous and contain } \\
\text { high concentrations of trilo- } \\
\text { bites and brachiopods. The } \\
\text { bioherms are not continuous } \\
\text { but occur in clusters, and are } \\
\text { separated from one another } \\
\text { where the bedrock surface is } \\
\text { eroded or intervening areas are } \\
\text { filled with marine sediments. }\end{array}$ \\
\hline $\begin{array}{l}\text { Silurian Blue- } \\
\text { Green Claystone }\end{array}$ & $\begin{array}{l}2-3 \mathrm{~m} \text { thick claystone and } \\
\text { forms a regional aquitard. }\end{array}$ \\
\hline $\begin{array}{l}\text { Silurian Lower } \\
\text { Limestone or } \\
\text { Dolomite }\end{array}$ & $\begin{array}{l}\sim 140 \text { m of limestone composed } \\
\text { of the lower Attawapiskat } \\
\text { formation, Ekwan River, and } \\
\text { Severn River formations. }\end{array}$ \\
\hline $\begin{array}{l}\text { Ordovician Red } \\
\text { Head Rapids and } \\
\text { Churchill River } \\
\text { Groups }\end{array}$ & $\begin{array}{l}\sim 50 \mathrm{~m} \text { thick mudstone that is } \\
\text { interbedded with limestones, } \\
\text { dolomites, and evaporites. }\end{array}$ \\
\hline
\end{tabular}

Table 1 Summary of main lithologic units

and between the Attawapiskat River and Nayshkootayaow River. The karst features include sinkholes, caves, sinking streams, and springs. Identification numbers 1-4, $6-8,12-15,18,021 \mathrm{~A}, 102,108,110,158,201$, and 204 are sinkholes observed during the karst feature survey. The surface elevation of the identified sinkholes varies from 58 to $90 \mathrm{~m}$ above mean sea level (amsl); whereas the springs were at elevations ranging from 50 to $80 \mathrm{~m}$ amsl. Additional sinkholes were reported at the Central Quarry and Process Plant sites. Because most of the study area was covered by muskeg, and many areas were inaccessible, the sinkhole study was based on analysis of existing borehole data, aerial observations in helicopter, and field verification along select transects. Not all sinkholes were identified in the study area. However, based on those identified at the Central Quarry, Process Plant, Bedrock Trench, Exploration Camp, and Bioherm Complex Zone, the sinkholes developed in the Paleozoic carbonate rocks within the James Bay lowland of Canada consist of pre-glacial sinkholes and post-glacial sinkholes. The pre-glacial sinkholes were identified at Central Quarry, Process Plant, and Bedrock Trench, whereas the post-glacial sinkholes were recognized at Exploration Camp and the Bioherm Complex Zone.

\section{Pre-glacial sinkholes}

Pre-glacial sinkholes formed in the geological past prior to land emergence, approximately 4,400 years ago (Cowell, 1983). They were buried by marine and alluvial deposits and were identified through quarrying, excavation, boreholes, and geophysical surveys. At least 16 pre-glacial sinkholes were uncovered after the thin overburden was removed over approximately $8,000 \mathrm{~m} 2$ at the Process Plant site. Figure 3 shows examples of

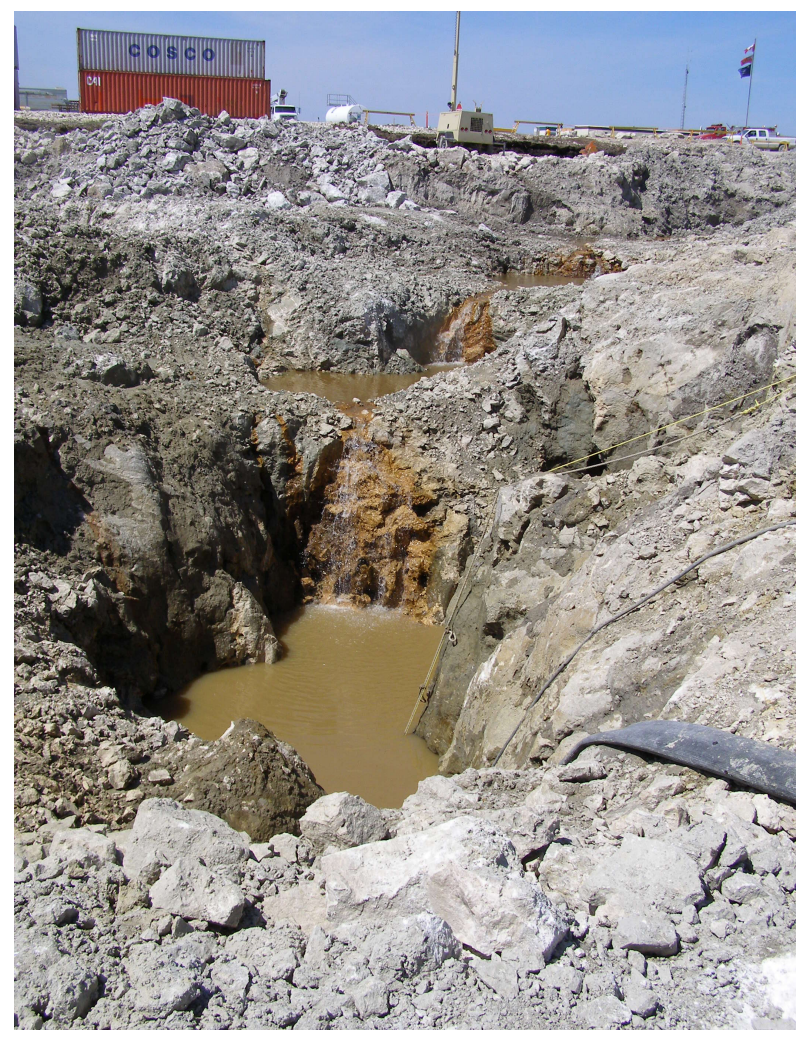

Figure 3 Pre-glacial sinkholes exposed at Process Plant site 
several such sinkholes. Their shapes are similar to "potholes" commonly observed in stream beds. All of these sinkholes displayed evidence of karstification and were filled with a mixture of sands, silt and clay along with pockets of gravel and rock fragments. Dissolution vugs/ cavities were present on the nearly vertical walls of these sinkholes.

The majority of the sinkholes occurred along a linear depression that ran northwest to southeast across the width of the north central portion of the Process Plant site. This feature was composed of what appeared to be a paleo-stream channel along with several deep depressions or pits. The largest of these depressions was $10 \mathrm{~m}$ long by $6 \mathrm{~m}$ wide and up to $7.5 \mathrm{~m}$ deep. They did not appear to drain water when they were exposed. The feature narrowed from top to bottom and was excavated to the depth where the backhoe bucket could not fit between the solid bedrock walls. Since this backhoe bucket was approximately a meter wide the true depth of the feature is unknown.

Two pre-glacial sinkholes were exposed on the walls of the Central Quarry. Figure 4 shows the cross section of the sinkhole at the north end of the quarry. This sinkhole was at least $10 \mathrm{~m}$ deep. Although the pre-glacial sinkholes were impermeable to water at the time of investigation, their hydrogeological properties are subject to change if they are reactivated by an increase in hydraulic gradient by mine dewatering (Glazek et al., 1989; Zhou, 1997).

Geophysical surveys and borehole drilling conducted during diamond exploration and a feasibility study revealed an irregular bedrock surface and one featured that

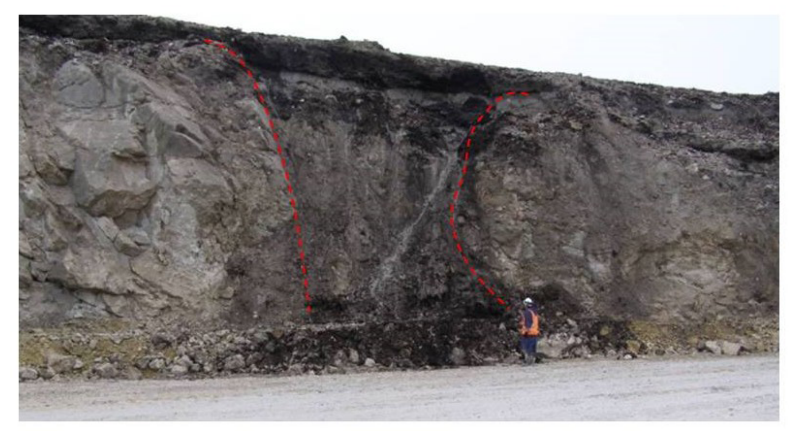

Figure 4 Buried sinkhole exposed in Central Quarry (dashed red lines indicating sinkhole walls) was referred to as the Bedrock Trench northeast of the Victor kimberlite (Hydrologic Consultants, Inc., 2007; Ontario Geological Survey, 2002). Boreholes at the perimeter of the trench encountered bedrock at depths between 20 and $30 \mathrm{~m}$ bgs, while boreholes in the Bedrock Trench intercepted the limestone bedrock at depths greater than $150 \mathrm{~m}$ bgs (Figure 5). The Bedrock Trench cut through most of the Paleozoic carbonates. Laterally, the shape of the Bedrock Trench is irregular and elongated in the northeast-southwest direction. The exact size of the trench could not be definitively determined but could be greater than $3 \mathrm{~km} 2$.

The Bedrock Trench is filled with unconsolidated materials that include glacial diamictons (tills), peat and organic detritus, lacustrine silts and clays, and sands and gravels (Gao et al., 2012). The depositional environment is perhaps similar to a polje, a steep-sided, internally drained, seasonal karst lake.

Such large-scale features as the Bedrock Trench do not usually result from a single process but from polygenetic processes including glacial scouring and bedrock dissolution. It is possible that an advancing ice sheet carved this trench along a structurally weakened zone with later bedrock dissolution as a modifying factor. Alternatively, the structurally weakened zone might be a karst feature such as a collapse or solution-enlarged fracture, which existed prior to glacial scouring. Because the Bedrock Trench is close to the Victor kimberlite pipe, it was also speculated that formation of the Bedrock Trench was associated with volcanic activities by fracturing the surrounding bedrock. An alternative interpretation was that the Bedrock Trench was an evaporite solution collapse structure that originated in the Churchill River and Red Head Rapids Group and has been modified in form by basal glacial scouring (Ford and Worthington, 2005).

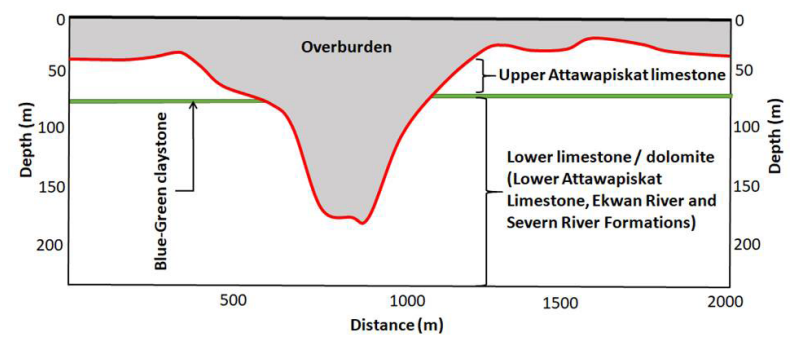

Figure 5 Schematic diagram of the Bedrock Trench 


\section{Post-glacial sinkholes}

The post-glacial sinkholes have developed after the area emerged from the Tyrrell Sea approximately 4,400 years BP. They occur in two regions, the reefal limestone of the upper Attawapiskat unit along the Attawapiskat River and Nayshkootayaow River and isolated bioherm outcrops in the peatland. The representative sinkholes along the major rivers were observed in the Exploration Camp area along the Nayshkootayaow River, whereas the example bioherm sinkholes were observed in the Bioherm Complex Zone between the Attawapiskat River and the Nayshkootayaow River. The two types of postglacial sinkholes correspond to the two distinct karst hydrogeological zones: the vadose fluvio-karst zone in the exposed limestone along the Attawapiskat River and the Nayshkootayaow River and an organo-karst zone on or next to limestone bioherms within the peat mantle (Cowell, 1983). The fluvial karst is most strongly affected by the two major rivers and associated processes; whereas the organo-karst is primarily affected by the peat deposits. Figure 6 shows the conceptual model of the postglacial sinkholes.

Sinkhole formation along the major rivers is driven by local water circulation that develops where the Attawapiskat River and the Nayshkootayaow River have cut through tens of meters into mid-Silurian limestone in response to the continuous isostatic uplift. The upper Attawapiskat limestone is either exposed or overlain by silty alluvium. The Attawapiskat and Nayshkootayaow Rivers are the dominant control for the water drainage and thus the depth of the karst dissolutions. The river entrenchment has dissected the limestones to create numerous islands and abandoned cut-off channels. Hydraulic gradient tends to be greater than 0.01 in the river cliffs. Some sinkholes appear to be drains of intermittent sinking streams and are connected to small caves. Because the groundwater along the major rivers tends to have a

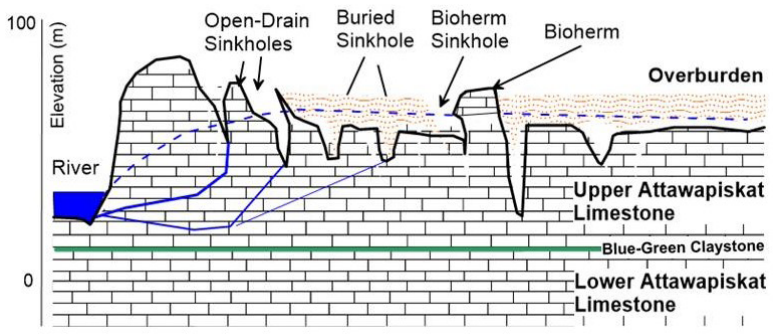

Figure 6. Conceptual model of post-glacial sinkholes
pH of greater than 7 (Sader et al., 2011), the groundwater is not aggressive in dissolving the limestones. These alluvial sinkholes are likely linked to the pre-glacial ones. The pre-glacial sinkholes provide the initial conditions for the post-glacial sinkhole formation, and the greater hydraulic gradient has been the force to erode away the in-fill materials.

As shown in Figure 6, the blue-green claystone is a key layer that affected the vertical extent of the post-glacial sinkholes. The majority of the sinkholes did not break through the claystone unless the pre-existing pre-glacial sinkholes were already deeper than the claystone.

In the flat-lying peatland, the marine deposits have acted as an aquiclude to prevent shallow peat water from draining vertically into the limestone beneath. The lateral drainage is also poor with hydraulic gradients of less than 0.002 . Sinkholes occur where the mild acidic water in the peat blanket ( $\mathrm{pH}$ values between 4 and 6 [Sader et al., 2011]) comes into lateral contact with reef knolls. Open bedrock cavities were present around several inland bioherms in the Bioherm Complex Zone between the Attawapiskat River and the Nayshkootayaow River. These ranged in size from relatively small openings to some large enough for a person to enter (Figure 7). The larger cavities appeared to be developed around the perimeter only and did not extend laterally into the bioherm mound. Through these various openings water could be heard and observed trickling downward.

Crescent-shaped sinkholes are another common feature observed around bioherms (Figure 8). Enhanced water recharge is anticipated within the crescent-shaped sink-

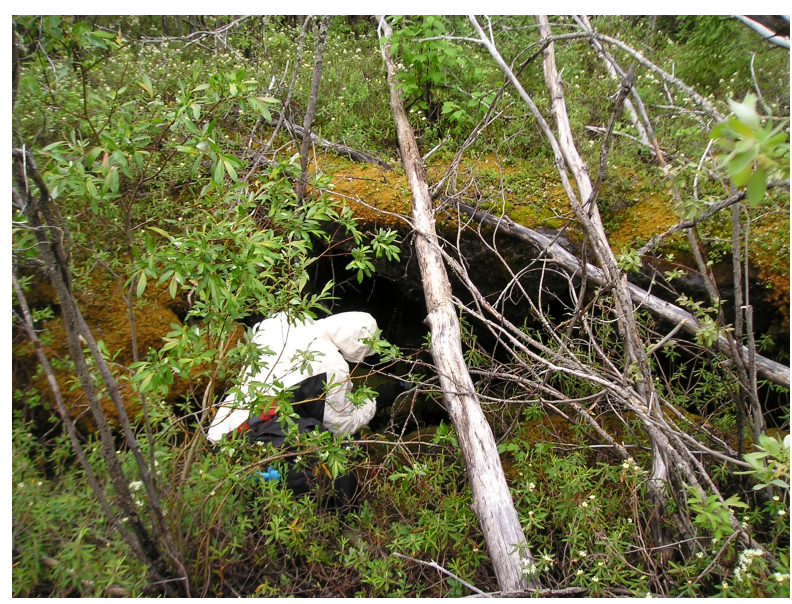

Figure 7. Sinkhole at perimeter of a bioherm 


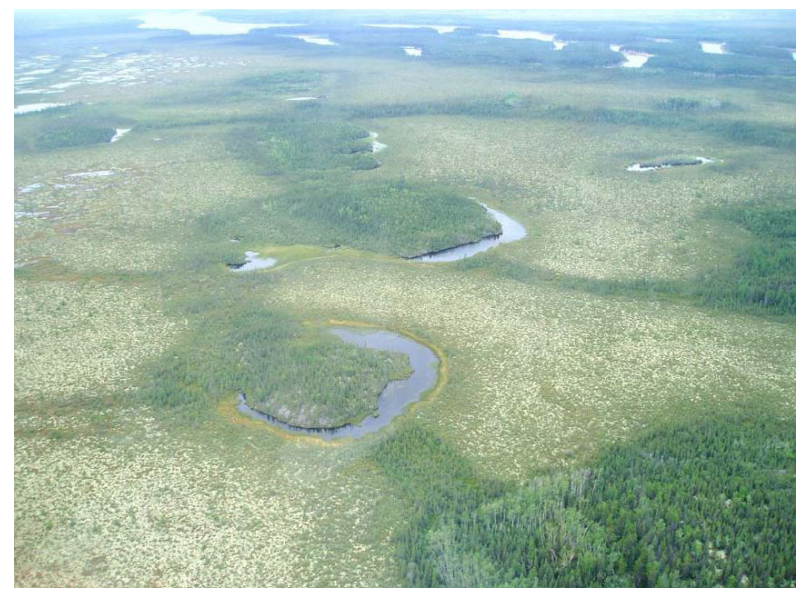

Figure 8. Crescent-shaped sinkholes at bioherms

holes. Review of these features from aerial photographs and helicopter flights indicates that they may actually be estavelles, which accept water during dry periods but contain and discharge water during wet periods. It should be noted that not all bioherms display sinkhole development; some of them show no apparent evidence of dissolution, particularly those north of the Attawapiskat River.

As discussed, hydraulic gradient has been an important factor in forming the post-glacial sinkholes. Because the shallow groundwater table varies seasonally, the waterlevel fluctuation may be another factor contributing their formation. High groundwater table conditions occur in spring and fall or following large rainfall events, raising the groundwater table into the upper, sponge-like section of peat (Whittington and Price, 2012). Conversely, there is relatively limited to almost no groundwater flow during drier periods and winter when the water table declines into the mud-rich sections of peat. Episodic fluctuations in groundwater level in the peat cause scouring of the sediments that were deposited in pre-existing karst features.

\section{Conclusions}

The study area of the James Bay lowland is underlain by limestones and dolomites that are susceptible to karst development. Two types of sinkholes were recognized in the study area: pre-glacial and post-glacial. The pre-glacial sinkholes are overlain by peat muskeg and marine and alluvial deposits and were identified at the Process Plant, Central Quarry, and Bedrock Trench sites.
The post-glacial sinkholes are surface features and occur in the reefal limestone of the upper Attawapiskat unit along the Attawapiskat River and the Nayshkootayaow River and around isolated bioherm outcrops in the peatland. The post-glacial and pre-glacial sinkholes exposed at the Process Plant and Central Quarry sites are relatively shallow and occurred in the upper Attawapiskat limestone, whereas the Bedrock Trench cut through most of the Paleozoic carbonates to a depth of approximately $200 \mathrm{~m}$ below ground surface. The post-glacial sinkholes have developed after the area emerged from the Tyrrell Sea approximately 4,400 years ago, and local water circulation is the driving force for their development. The post-glacial sinkholes are part of the current hydrogeological karst system, whereas the pre-glacial sinkholes tend to be dormant until they are reactivated. Recognition of these two types of sinkholes is informative to understanding of the hydrogeological conceptual site model for the groundwater simulation and evaluation of the environmental impact of dewatering in the Victor mine. Although the acidic peat water contributes to all postglacial sinkhole formation including those at bioherms, the majority of the post-glacial sinkhole occurrence is likely linked to the pre-glacial ones, which provided the initial conditions for their formation. Understanding of post-glacial sinkhole development requires knowledge of the pre-glacial sinkholes. The increases in hydraulic gradient in response to the isostatic uplift and seasonal fluctuations in shallow groundwater level have helped reactivate the pre-glacial sinkholes and have been the primary force causing erosion of the materials overlying them. While the formation of the Bedrock Trench is debatable, the trench may have resulted from polygenetic processes including glacial scouring and bedrock dissolution.

\section{References}

Atkinson LC, Keeping PG, Wright JC, Liu H. 2010. The challenges of dewatering at the Victor Diamond Mine in northern Ontario, Canada. Mine Water Environ, 29:99-107, doi: 10.1007/s10230010-0109-1.

Cowell DW. 1983. Karst hydrology within a subarctic peatland: Attawapiskat River, Hudson Bay lowland, Canada. Journal of Hydrology, 61: 169175.

Cowell DW. 2004. Review of impacts and boundaries of the Attawapiskat karst and peatland candidate 
area of natural and scientific interest. Submitted to Ontario Ministry of Natural Resources, Division of Parks, Ontario.

Ford D, Worthington SRH. 2005. Letter comment on the De Beer Victor Diamond Project comprehensive study. Submitted to Canadian Environmental Assessment Agency.

Gao C, McAndrews JH, Wang X, Menzies J, Turton CL, Wood BD, Pei J, Kodors C. 2012. Glaciation of North America in the James Bay lowland, Canada, 3.5 Ma. Geology, 40(11): 975-978, doi: 10.1130/G33092.1.

Gautrey S. 2018. A comparison of predicted groundwater impacts to observed effects at the Victor Diamond Mine, 11 years after the start of dewatering. Proceedings of Mine Water Solutions 2018, June 12-16, Vancouver, Canada.

Glazek J, Bosak P, Ford DC. 1989. Paleokarst as a problem. In Paleokarst, A Systematic and Regional Review, Elsevier and Academia, Amsterdam and Prahana.

Hydrologic Consultants, Inc. 2007. Dewatering of Victor Diamond Mine predicted engineering and environmental factors, June, unpublished report.

Ontario Geological Survey. 2007. Precambrian geology, Hudson Bay and James Bay lowlands region interpreted from aeromagnetic data, east sheet. Queen's Printer for Ontario, Canada, Map P.3598, scale 1:500,000, http://www.geologyontario. mndm.gov.on.ca/mndmfiles/pub/data/imaging/ P3598//P3598.pdf,

Ontario Geological Survey. 2002. Drift deposits in drill holes V01-190c and V01-191c at Victor Kimberlite pipe, northern Ontario. Sedimentary Geoscience Section, Ontario Geological Survey.

Sader JA, Hattori KH, Kong JM, Hamilton SM, Brauneder K. 2011. Geochemical responses in peat groundwater over Attawapiskat kimberlites, James Bay lowlands, Canada, and their application to diamond exploration. Geochemistry: Exploration, Environment, Analysis, 11: 193-210, doi: 10.1144/1467-7873/10-030.

Webb KJ, Smith BHS, Paul JL, Hetman CM. 2004. Geology of the Victor Kimberlite, Attawapiskat, northern Ontario, Canada: cross-cutting and nested craters. Lithos, 76: 29-50, doi:10.1016/j. lithos.2004.03.050.

Whittington P, Price J. 2012. Effect of mine dewatering on peatlands of the James Bay lowland: the role of bioherms. Hydrological Processes, doi: 10.1002/ hyp. 9266 .

Wood BD, Smith BHS, Rameseder B. 2013. The Victor Diamond Mine, northern Ontario, Canada: successful mining of a reliable resource. D. G. Pearson et al. (eds.), Proceedings of 10th International Kimberlite Conference, Volume 2, Special Issue of the Journal of the Geological Society of India, doi: 10.1007/978-81-322-1173$0 \_2$.

Zhou W. 1997. Paleocollapse structure as a passageway for groundwater flow and contaminant transport, Environmental Geology, 32(4): 251-257. 